\title{
Revision of the Palaearctic members of the species complex resembling Megaselia brevior (Schmitz) (Diptera: Phoridae)
}

\author{
R. Henry L. DiSNEY \\ * University of Cambridge Museum of Zoology, Downing Street, Cambridge CB2 3EJ, U.K.; \\ e-mail: rhld2@hermes.cam.ac.uk
}

\begin{abstract}
The complex of species resembling Megaselia brevior (Schmitz) is revised. M. angustiata Schmitz and M. parvula Schmitz are reinstated as valid species. The following new synonyms are proposed: M. aspera Schmitz (male holotype only) is synonymised with M. leucozona Schmitz; M. ultrabrevis Schmitz, and its synonym M. pseudobrevior Disney, are synonymised with M. angustiata; and M. insecta Schmitz is synonymised with M. oxybelorum Schmitz. The female paratype of $M$. aspera is recognised as a female of $M$. parvula. A key to the Palaearctic species of this subgroup is provided.
\end{abstract}

Key words: Phoridae, Palaearctic, reinstated species, synonyms

\section{INTRODUCTION}

The genus Megaselia Rondani (1857) currently includes around 1400 species, but far more remain to be described. A particularly troublesome group are those that are only 1-2 $\mathrm{mm}$ long, with a bare mesopleuron, and the wing with a shortened costa. With both the Afrotropical and the Palaearctic members of this complex the difficulties of species recognition have been compounded by several species being described from very few specimens, often from one sex only. When the latter has been a male the hypopygium has not being illustrated. Furthermore, prior to the 1970s these flies were studied at low magnifications, either as pin-mounted specimens or in alcohol, apart from an occasional detached wing mounted on a slide. Consequently, excessive emphasis was given to small details of the wing, such as the costal index, with little or no attempt to consider how variable these might be or any sexual dimorphism with respect to these details. Furthermore a feature of this group of species is that they tend to vary in size, with consequential variations in the ratios of the wing measurements (e.g. see under M. parvula below).

The procuremet of a good series of both sexes of a species of this complex in the United Arab Emirates (UAE) prompted a critical review as its identification was attempted. As the UAE straddles the boundary between the Palaearctic and Afrotropical Regions it was necessary to consider the species of both these regions.

Afrotropical members of this complex have proved especially troublesome in that many species run to the same two couplets in the keys of Beyer (1965). Furthermore, these keys omitted species from the Seychelles described by Collin (1912) but which Beyer decided to ignore. Others running to the same couplets have been described since (Disney 1991a, b, c, 2005). However, the specimens from the UAE fitted none of these, but showed affinity with a subset of the Palaearctic species of this complex.

With regard to the Palaearctic species, between 1924 and 1957 Schmitz described a series of species, but he frequently failed to highlight their diagnostic features in relation to each 
other or to previously described species, apart from supposed differences in the wings. An initial revision of the Palaearctic species of a subset of this complex, namely those with yellow haltere knobs, was based on slide mounted specimens (Disney 1988). With the acquisition of further material, now mounted on slides, it has become apparent that the three species added by Schmitz (1930), which were all reared together from locust egg pods in Dagestan, have caused particular confusion due to incorrect associations of males and females. Indeed, it now seems Schmitz's associations of the sexes were based on the wings, without realising that there is a sexual dimorphism in the ranges of variation for the various wing measurements and their ratios. In this paper a subset of the Palaearctic species of this complex is revised, following the acquisition of further fresh material mounted on slides in addition to the UAE specimens.

Species of the $M$. brevior complex are only 1-2 mm long, with a bare mesopleuron, the wing with a shortened costa and the haltere knob is a pale straw yellow. They are mainly dark brown, including at least the hind femora being essentially brown, they have several SPS vesicles (subcuticular pit sensilla) in each postpedicel and only two bristles on the notopleuron. The males have a proboscis with relatively few, scattered, pale spinules on their lower faces and they lack a notopleural cleft. Several other species resemble these but differ by at least one feature. For example M. berndseni (Schmitz) lacks SPS vesicles but has densely spinose labella, but otherwise agrees. The male of $M$. brevicostalis (Wood) has a notopleural cleft (Fig. 32), and is thereby excluded. However, its female fits this diagnosis and is therefore included in the key below.

\section{METHODS}

This revision is based on slide mounted specimens (Disney 2001).

\section{REVIEW OF SPECIES}

The Palaearctic species of the $M$. brevior complex now regarded as being valid are reviewed below, taken in the order in which they were originally described (except for one species).

\section{Megaselia brevior (Schmitz)}

(Figs 1-4)

Aphiochaeta brevior Schmitz 1924a: 130.

Megaselia brevior (Schmitz). Schmitz 1928: 132.

Megaselia berndseni various authors. Misidentifications.

The type material came from Germany. I have specimens from Austria, England, Spain and Switzerland.
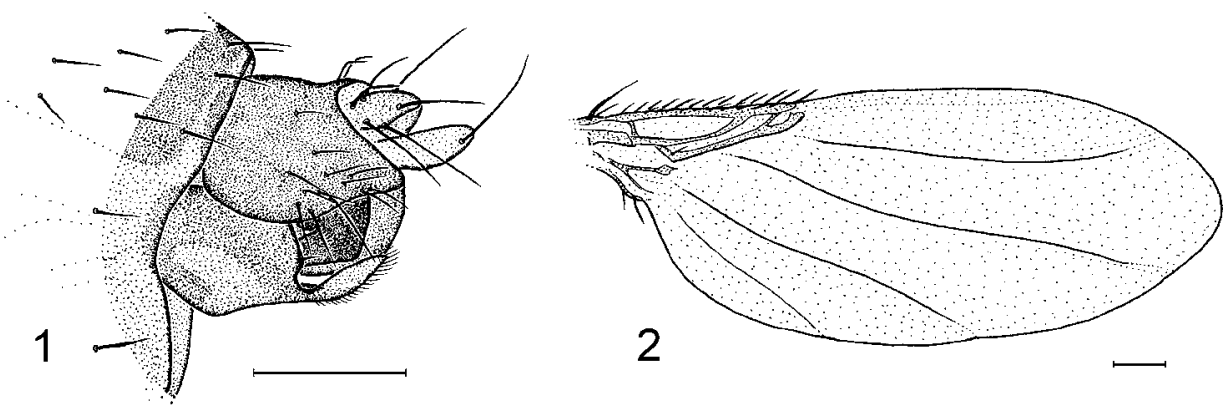

Figs 1-2. Megaselia brevior male. 1 - left face of hypopygium. 2 - right wing. Scale bars $=0.1 \mathrm{~mm}$. 

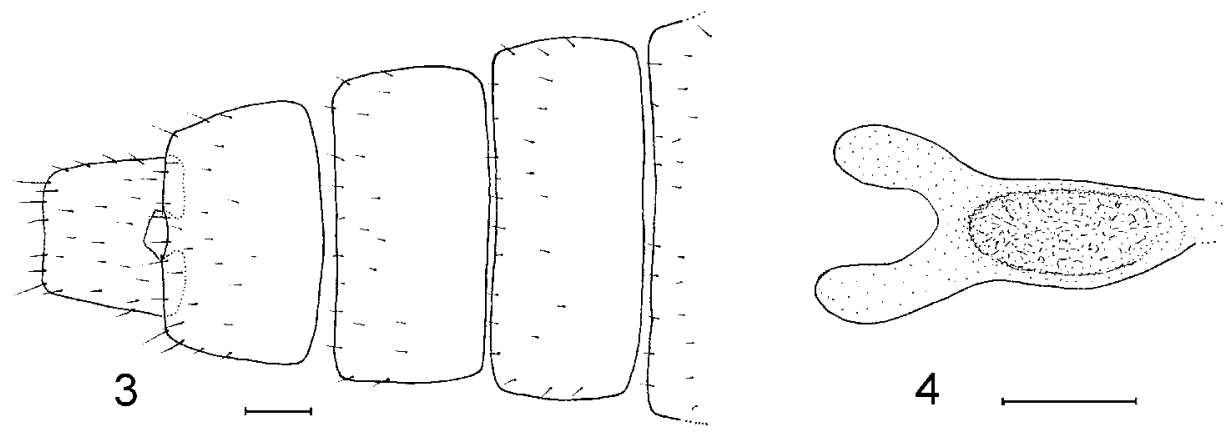

Figs 3-4. Megaselia brevior female. 3 - abdominal tergites, rear of T2 to T6. 4 - Dufour's crop mechanism. Scale bars $=0.1 \mathrm{~mm}$.

\section{Megaselia brevissima (Schmitz)}

(Figs 5-7)

Aphiochaeta brevissima Schmitz 1924b: 85 .

Megaselia brevissima (Schmitz). Schmitz 1928: 132.

The type material came from Croatia. I have specimens from the Canary Islands.
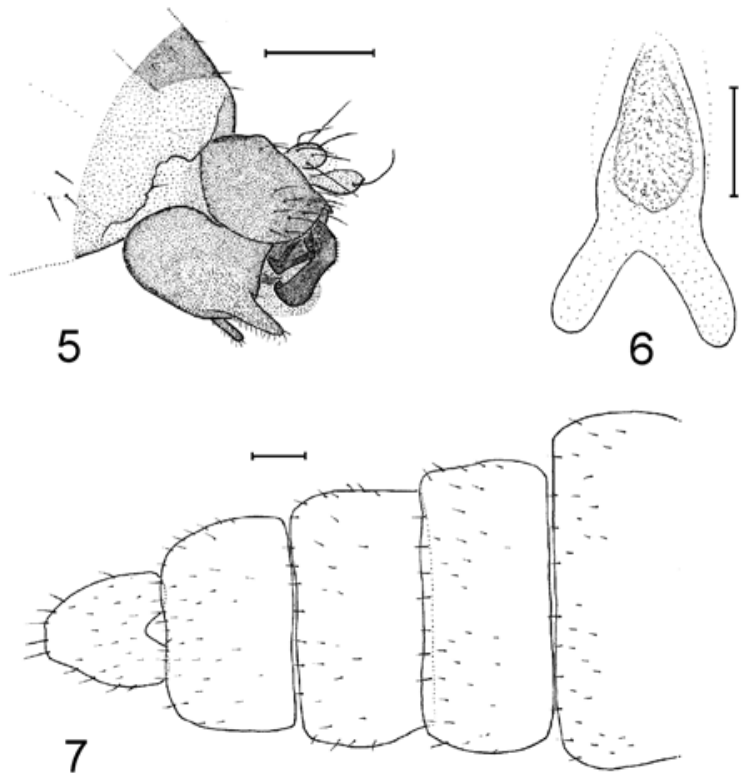

Figs 5-7. Megaselia brevissima. 5 - left face of male hypopygium. 6 - female, Dufour's crop mechanism. 7 - female abdominal tergites, rear of T2 to T6. Scale bars $=0.1 \mathrm{~mm}$. 


\section{Megaselia oxybelorum Schmitz}

(Figs 8-12)

Megaselia oxybelorum Schmitz 1928: 131.

Megaselia insecta Schmitz 1953: 207. Syn nov.

The type series of $M$. oxybelorum came from Versailles in Northern France and includes both sexes. The only figure is that of a wing. As with other members of this complex, the variation in the size of this species has been a source of confusion. $M$. insecta was described from a single male from Romania. The only figure was of the male wing. Its costal index was 0.35 . The holotype has since been destroyed by fire. It is evident, however, that the supposed difference between the wings is not diagnostic as both its costal index and ratios are now perceived to fall well within range of variation that exists in this species. It is therefore formally synonymised with $M$. oxybelorum.

I have specimens from Italy, Spain and the Canary Islands (Disney et al., 1990).

In Europe it has been reared from the fly Fannia scalaris (Fabr.) (Fanniidae) when paralysed and used to provision the nest of the wasp Oxybelus uniglumis (L.) (Crabronidae) (Chevalier 1925, Schmitz 1928). Females have been observed entering the nests of the wasp Cerceris arenaria (L.) (Philanthidae) (Polidori et al. 2001).

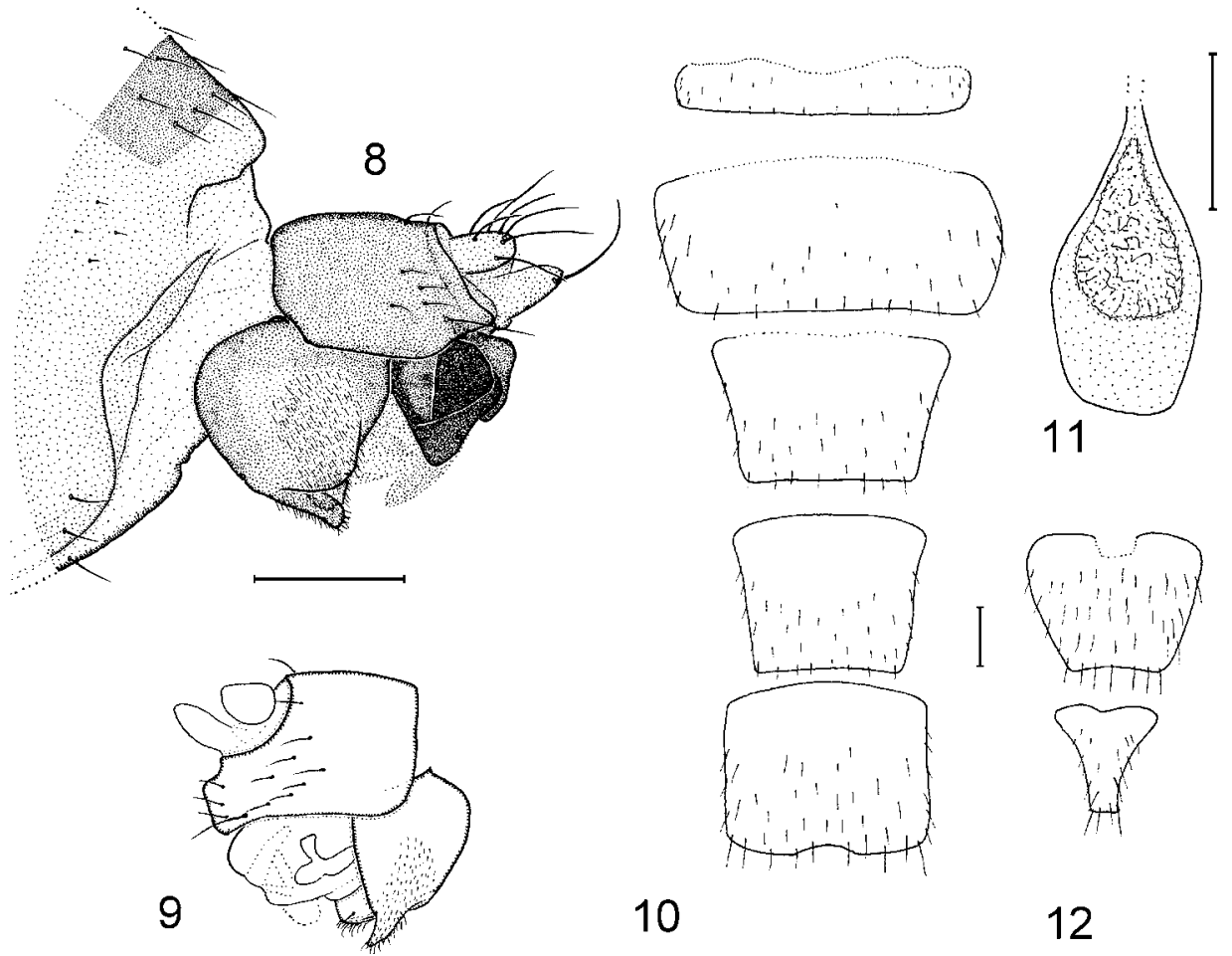

Figs 8-12. Megaselia oxybelorum. 8 - male, left face of hypopygium; 9 - male, right faces of epandrium and hypandrium; 10 - female, abdominal tergites $1-5 ; 11$ - female, Dufour's crop mechanism.; 12 - female, tergites 6-7. Scale bars $=0.1 \mathrm{~mm}$. 


\section{Megaselia leucozona Schmitz}

(Figs 13-16)

Megaselia leucozona Schmitz 1930: 67.

Megaselia aspera Schmitz 1930: 68 (holotype male only). Syn. nov.

The single, holotype female of M. leucozona came from Dagestan. The only figure was of the wing. The male was subsequently described, from a good series of both sexes collected in Italy, by Disney (in Polidori et al. 2005) and the description of the female amplified. It is now apparent that the various wing measurement ratios for the male holotype of $M$. aspera from Dagestan fall within the ranges for M. leucozona. Consequently M. aspera is herewith formally synonymised with this species. The associated female, however, has wing measurements that are consistent with those of $M$. parvula (see below).

This species has been reared from the egg pods of the locust Locusta migratoria L. in Dagestan (Schmitz 1930). It has also been reported entering the nests of sweat bees (Halictidae) in Italy (Polidori et al. 2005).
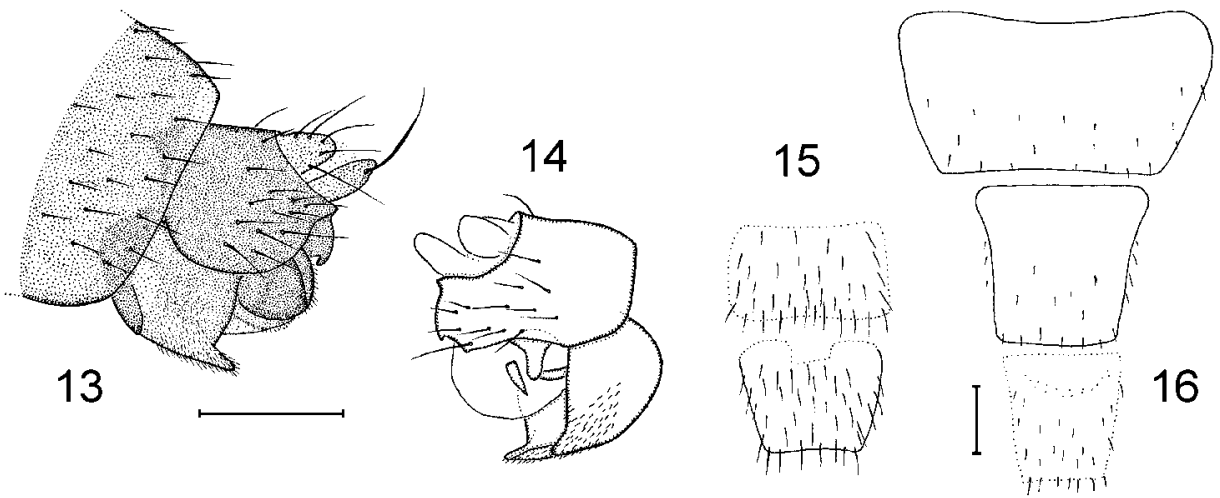

Figs 13-16. Megaselia leucozona. 13 - left face of male hypopygium. 14 - right faces of epandrium and hypandrium. $15-16$ - female abdominal tergites $2-6$. Scale bars $=0.1 \mathrm{~mm}$.

\section{Megaselia parvula Schmitz}

(Figs 17-21)

Megaselia parvula Schmitz 1930: 69. Resurrected from synonymy.

Megaselia aspera Schmitz 1930: 68 (female paratype only). Misidentification.

This species, whose type series was from Dagestan, was synonymised with M. brevissima (Disney 1988). It is now formally reinstated and the female paratype of $M$. aspera recognised as belonging to M. parvula (the male holotype of $M$. aspera being that of the previous species).

A recently collected series of 24 males and 9 females from the United Arab Emirates give the following ranges for details of the wings. Males: wing length $1.0-1.7 \mathrm{~mm}$. Costal index 0.28-0.33. Costal ratios 4.2-5.9: 1.0-1.8. Costal cilia (of section 3) 0.06-0.09 mm long. Females: wing length $0.9-1.7 \mathrm{~mm}$. Costa index 0.31-0.39. Costal ratios 3.3-5.9: 0.9-1.6 : 1 . Costal cilia $0.05-0.09 \mathrm{~mm}$ long. This species closely resembles $M$. oxybelorum. The otherwise distinctive female differs by the form of its abdominal tergite 7 (Fig. 21) and in its possession of a sclerotised furca (Fig. 20), which may appear as an irregular dark brown bar if seen edge on. No such furca is evident in females of M. oxybelorum.

This species has been reared from the egg pods of the locust Locusta migratoria L. (Schmitz 1930). 


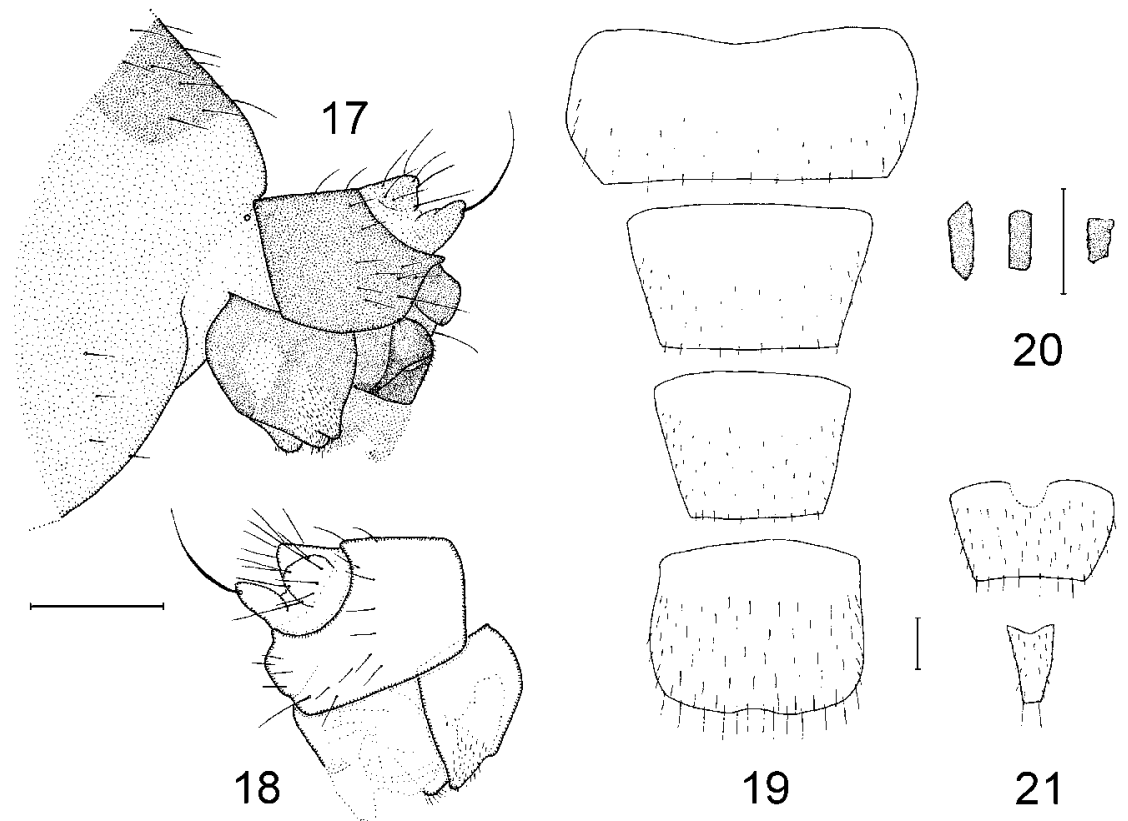

Figs 17-21. Megaselia parvula. 17 - male, left face of hypopygium; 18 - male, right faces of epandrium, hypandrium and anal tube; 19 - female, abdominal tergites 2-5. 20 - female, furcas (internalised sternite 9) of three different specimens. $21-$ female, tergites $6-7$. Scale bars $=0.1 \mathrm{~mm}$.

\section{Megaselia exsecta Schmitz}

(Fig. 22)

Megaselia exsecta Schmitz 1957: 239.

This species was described from a single female and a somewhat damaged male from Spain. The wing of the former was figured along with its distinctive abdominal tergites (Fig. 22).
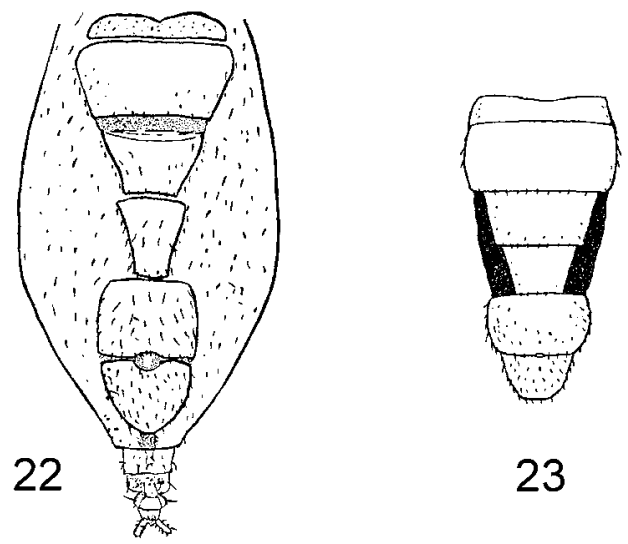

Figs 22-23. Megaselia females, abdominal tergites 1-6; 22 - M. exsecta (from Schmitz, 1957); 23 - M. intersecta (from Schmitz, 1935). Scale bars $=0.1 \mathrm{~mm}$. 


\section{Megaselia intersecta Schmitz}

(Fig. 23)

Megaselia intersecta Schmitz 1935: 13.

This species was described from a single female from Jerusalem. A wing was figured, and also the abdominal tergites (Fig. 23).

\section{Megaselia angustiata Schmitz}

(Figs 24-26)

Megaselia angustiata Schmitz 1936: 76. Resurrected from synonymy.

Megaselia ultrabrevis Schmitz 1937: 126. Syn. nov.

Megaselia pseudobrevior Disney 1988: 157. Syn. of M. ultrabrevis, Disney 2003: 297.
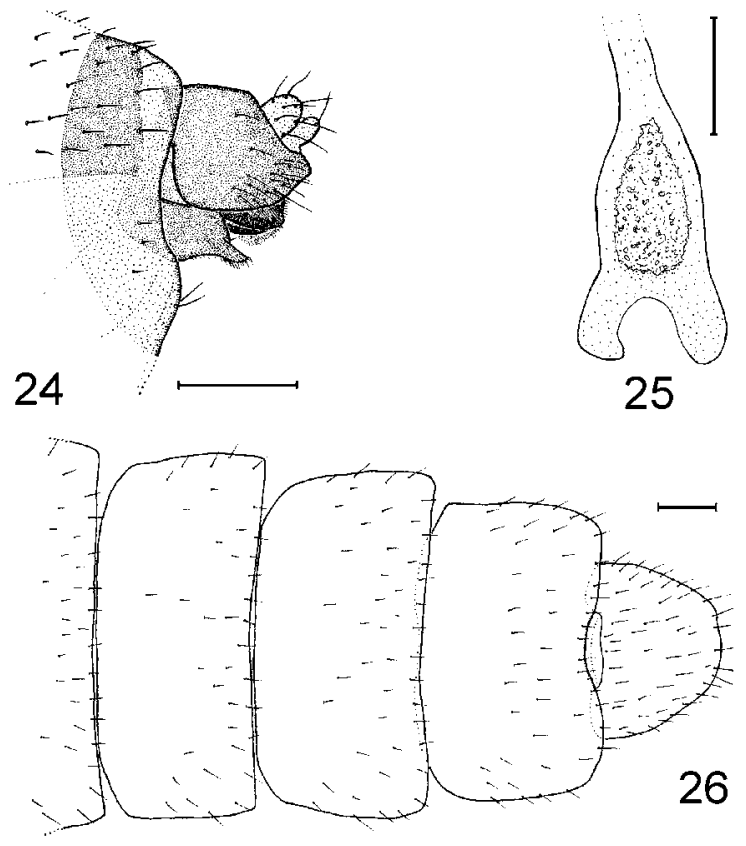

Figs 24-26. Megaselia angustiata. 24 - left face of male hypopygium; 25 - female, Dufour's crop mechanism; 26 female abdominal tergites, rear of $\mathrm{T} 2$ to $\mathrm{T} 6$. Scale bars $=0.1 \mathrm{~mm}$.

This species was described from a single female from the Canary Islands and the only figure was of the wing, whose costal index was $0.37-0.38$. With the procurement of further material of $M$. oxybelorum (see above) it is now concluded that the synonymy of $M$. angustiata with the latter species was incorrect. Furthermore, when Schmitz described both sexes of $M$. ultrabrevis he provided no figures but emphasised that the costal index was only $0.26-0.27$ (as reflected in the name). Consequently a further series from the Canary Islands, with the costal index of 0.34-0.36, were assigned to the new species $M$. pseudobrevior. However, when a syntype (labelled as a cotype) of $M$. ultrabrevis was subsequently remounted on a slide it was found to have a costal index of 0.30-0.32. Furthermore additional specimens of $M$. pseudobrevior included some with the CI as low as 0.30 . The latter species was therefore 
synonymised with $M$. ultrabrevis by Disney (2003a). With the procurement of further material it is evident that the costal index ranges from 0.26-0.38. Indeed Schmitz's reliance on a supposed small difference in the costal index and ratios as a basis for recognising this species has proved to be highly misleading. Consequently it is now proposed that M. angustiata be reinstated as a valid species, but $M$. ultrabrevis be synonymised with it (and thus also $M$. pseudobrevior). I have many specimens from the Canary Islands, the Azores, Madeira and Spain.

\section{Megaselia stenoterga Disney}

(Figs 27-31)

Megaselia stenoterga Disney 1990: 158.

The type series was from the Canary Islands.
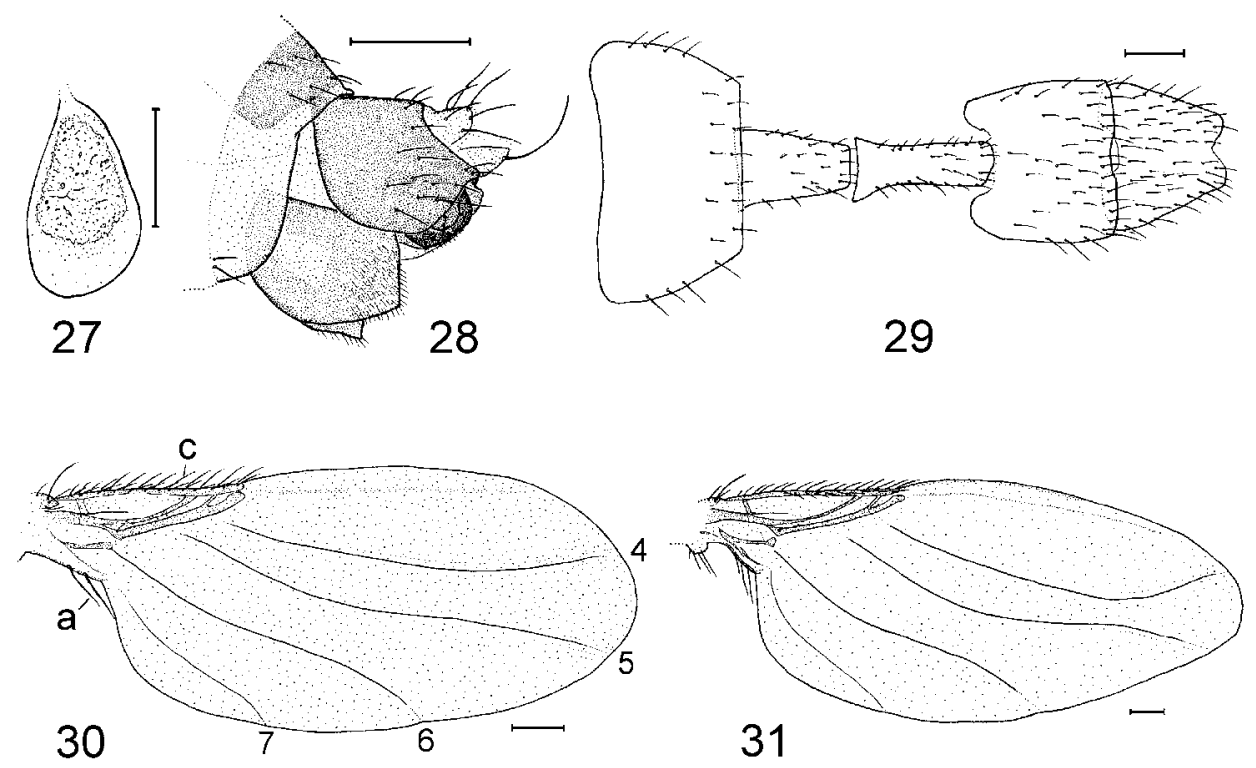

Figs 27-29. Megaselia stenoterga. 27 - female, Dufour's crop mechanism. 28 - left face of male hypopygium; 29 female abdominal tergites, T2 to T6; $30-$ male, right wing $(\mathrm{c}=$ costal cilia, a = axillary bristles, 4-7 = veins 4-7), 31 female, right wing. Scale bars $=0.1 \mathrm{~mm}$.

\section{KEY TO THE PALAEARCTIC SPECIES OF THE MEGASELIA BREVIOR SPECIES COMPLEX}

Note: The male of $M$. intersecta is unknown. The male of $M$. exsecta is not recognisable from its description, which lacks figures, and how it differs from the males of previously published species was not indicated. Furthermore its male paratype was not caught in association with the holotype female, so its specific assignment must remain questionable. Therefore the males of both these species are absent from the key. The male of $M$. brevicostalis is excluded because it has a notopleural cleft (Fig. $32 \mathrm{c}$ ), but its female falls within this group and is therefore included in the key. 


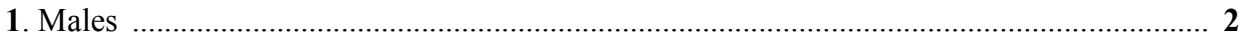

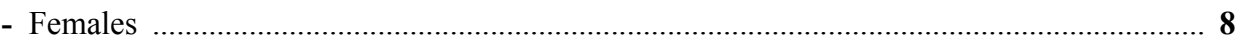

2. Hairs at tip of proctiger at most subequal to hairs on cerci and a pair of lobes of hypandrium evident even if a little short, especially the shorter one of the right side (Figs 1, 5 and 24)

- Hairs at tip of proctiger distinctly more robust and a little to clearly longer than hairs on cerci and lobes of hypandrium evident (Fig. 13) or vestigial (Figs 8, 17 and 28) ............... 5

3. Hairs at tip of proctiger shorter than hairs on cerci and left lobe of hypandrium short (Fig. 24) M. angustiata Schmitz

- Hairs at tip of proctiger longer (being subequal to all but the longest hairs on cerci) (Figs 1 and 5)

4. Hairs at rear of T6 longer and left lobe of hypandrium larger (Fig. 1) .... M. brevior (Schmitz)

- Hairs at rear of T6 shorter and likewise left lobe of hypandrium (Fig. 5) M. brevissima Schmitz

5. Left lobe of hypandrium abbreviated, being largely vestigial (Figs 8,17 and 28) ............ 6

- Left lobe of hypandrium as in Fig. 13 M. leucozona Schmitz

6. Veins 4 and 5 divergent throughout (as in Fig. 2) 7

- Veins 4 and 5 subparallel in middle third (Fig. 30). (Hypopygium as Fig. 28)

7. Hypopygium as in Fig. 17

M. stenoterga Disney

- Hypopygium as in Fig. 8

M. parvula Schmitz

8. Abdominal tergites 3 and 4 clearly narrow so that they are much longer than broad (Fig. 29). Veins 4 and 5 in outer half of wing strongly converge and then diverge (Fig. 31)

M. stenoterga Disney

- Without these features combined

9. Abdominal tergites progressively narrower from T2 onwards (Figs 3, 7 and 26). (Rear of Dufour's crop mechanism divided into two lobes (Figs 4, 6 and 25)

- Width of hind margin of T4 less than front margin of T5 (Figs 10, 15-16, 19, 22 and 23). (Where known, DCM is rounded behind (e.g. Fig. 11) .................................................. 13

10. Hind margin of T6 more-or-less straight (Fig. 3) or slightly concave ((Fig. 34) ............... 11

- T6 with a more-or-less rounded hind margin (Figs 7 and 26) ......................................... 12

11. Abdominal sternite 7 as Fig. 35. A well sclerotised furca and a pair of vaginal sclerites as in Fig. 36

M. brevicostalis (Wood)

- Abdominal sternite 7 a narrow bar that is only slightly wider at hind margin, which bears only a single pair of hairs. No furca or vaginal sclerites evident M. brevior (Schmitz)

12. T5 with more pronounced median embayment of hind margin and T6 broader (Fig. 26). Greatest breadth of labrum subequal to diameter of postpedicel M. angustiata Schmitz

- T5 with a less obvious embayment of hind margin and T6 narrower (Fig. 7). Greatest breadth of labrum a little larger than diameter of postpedicel M. brevissima Schmitz

13. Abdominal tergites 3 and 4 longer than broad (Fig. 3) and $T 5$ and at least most of T4 straw yellow M. leucozona Schmitz

- Without this combination 14

14. T4 longer than greatest breadth and strongly tapered and T6 tapering to narrowly rounded rear margin (Fig. 22) M. exsecta Schmitz

- Not so 15

15. Rear margin of T6 straight to slightly concave (Figs 12 and 21) 16

- Rear margin of T6 as Fig. 23

16. $\mathrm{T} 7$ as Fig. 12. Furca (internalised sternite 9) not sclerotised M. intersecta Schmitz

- T7 as Fig. 21. Furca (seen from above) light brown and as Fig. 20 (in side view it as an irregular dark brown strip) M. parvula Schmitz 


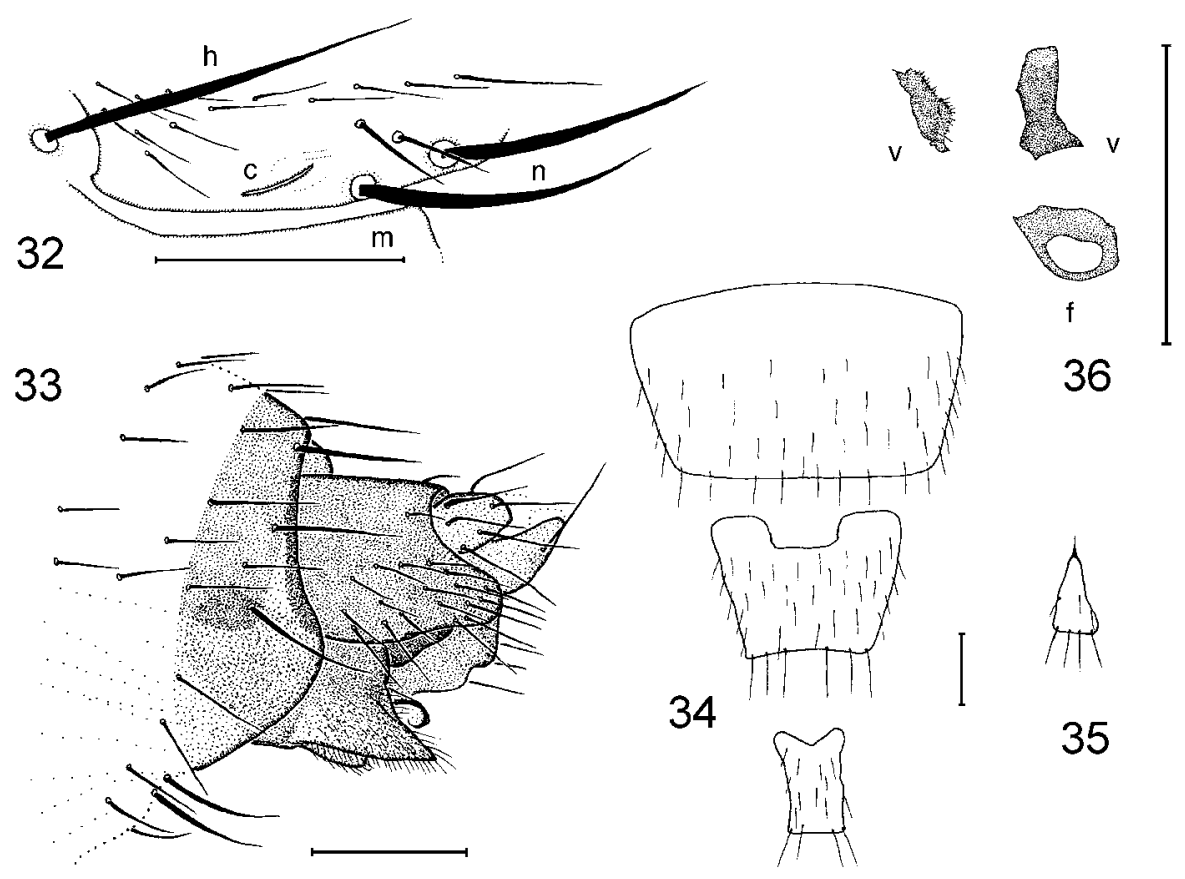

Figs 32-36. Megaselia brevicostalis. 32 - male, left notopleuron $(\mathrm{h}=$ humeral bristle, $\mathrm{c}=$ notopleural cleft, $\mathrm{m}=\mathrm{upper}$ edge of mesopleuron, $\mathrm{n}=$ notopleural bristles); 33 - male, left face of hypopygium; 34 - female, abdominal tergites 5-7; 35 - sternite 7; 36 - vaginal sclerites (v) and furca (f). Scale bars $=0.1 \mathrm{~mm}$.

\section{COMMENT}

It is evident that associating the sexes on the basis of similarity of the ratios of the wing measurements is likely to be misleading due a small degree of sexual dimorphism that is evident with respect to these ratios. Indeed very similar ratios in specimens of different sexes are more likely to indicate that they belong to different species. Furthermore, variations in the sizes of specimens of the same species increases the ranges of variation for these ratios. Experience indicates that identifications of specimens of this species complex that are not based on slide mounts are suspect.

\section{ACKNOWLEDGMENTS}

My continuing work on Phoridae has benefited from a grant from the Professor Hering Memorial Research Fund (British Entomological \& Natural History Society).

\section{REFERENCES}

Beyer E. M. 1965. Phoridae (Diptera Brachycera). Exploration du Parc National Albert, Mission G. F. De Witte (1933-1935) 99: 1-211.

Chevalier L. 1925. Phora pygmaea Zett. Diptère mangeur de mouches. Bull. Soc. Sci. Seine-et-Oise 6: 93-96.

ColLIN J. E. 1912. Diptera. Phoridae from Seychelles. Trans. Linn. Soc., London 15: 105-118. 
Disney R. H. L. 1988. The Palaearctic species resembling Megaselia pygmaea (Diptera, Phoridae), including two new species. Ann. Ent. Fenn. 54: 153-161.

DISNEY R. H. L. 1991a. Scuttle flies from Zimbabwe (Diptera, Phoridae) with the description of five new species. J. African Zool. 105: 27-48.

DiSNEY R. H. L. 1991b. The Ascension Island scuttle fly (Diptera: Phoridae). Entomologist 110: 82-93.

DiSNEY R. H. L. 1991c. Scuttle flies of the Cape Verde Islands (Diptera, Phoridae). J. African Zool. 105: 205-241.

DiSNEY R. H. L. 2001. The preservation of small Diptera. Entomologist's Mon. Mag. 137: 155-159.

DISNEY R. H. L. 2003. Revisionary notes on European Phoridae (Diptera). Bonn. Zool. Beitr. 50: 293-304.

DISNEY R. H. L. 2005. Phoridae (Diptera) of Madagascar and nearby islands. Stud. dipterol. 12: 139-177.

Disney R. H. L., BAeZ M., Ashmole N. P. 1990. A revised list of Phoridae (Diptera) from the Canary Islands, with habitat notes. Vieraea 18: 261-265.

Polidori C., Disney R. H. L., ANDRIETTI F. 2001. Some behavioural observations on Megaselia oxybelorum (Diptera: Phoridae), a new kleptoparasite of Cerceris arenaria (Hymenoptera: Sphecoidea: Philanthidae). Brit. J. Ent. Nat. Hist. 14: 93-95.

Polidori C., Boesi R., ANDrietti F., Disney R. H. L. 2005. Association of the scuttle fly Megaselia leucozona SCHMitz (Diptera: Phoridae) with sweat bees (Hymenoptera: Halictidae), with a description of the male fly. Entomologica fennica 16: 144-150.

SCHMitz H. 1924a. Mitteilungen über allerlei Phoriden. Natuurh. Maandbl. 13: 129-131.

SCHMITZ H. 1924b. Europäische Phoriden des Ungarischen National-Museums. Ann. Mus. Natn. Hung. 21: $79-86$.

SCHMitZ H. 1928. Verslag der Maandelijksche vergadering 5. September L. L. - Megaselia oxybelorum n. sp. Natuurh. Maandbl. 17: 121-122, 131-132.

SCHMitz H. 1930. Phoriden aus Eipaketen von Locusta migratoria in Daghestan. Natuurh.. Maandbl. 19: 67-69.

SCHMiTZ H. 1935. Neue paläarktische Phoriden. Broteria 31: 5-16.

Schmitz H. 1936. Phoridae. In Frey, R. (Editor) Die Dipterenfauna der Kanarishen Inseln und ihre Probleme. Soc. Sci. Fennica Comment. Biol. 6: 70-82.

SCHMITZ H. 1937. Spanische Phoriden des Madrider Museums. Broteria 33: 119-127.

SCHMITZ H. 1953. Ungarische und andere paläarktische Phoriden des Ungarischen Nationalmuseums (Diptera). Anals Hist.-Nat. Mus. Nation. Hung. Budapest. 3: 203-211.

SCHMITZ H. 1957. Zoologisch-systematische Ergebnisse der Studienreise von H. Janetschek und W. Steiner in die spanische Sierra Nevada 1954. IV. Phoridae (Diptera). Stz. Öst. Akd. Wiss. Math.-nat. K1. Abt. I, 166: 231-247.

\section{STRESZCZENIE}

\section{[Rewizja palearktycznych gatunków należących do grupy Megaselia brevior (Schmitz) (Diptera: Phoridae)]}

Artykuł dotyczy 9 palearktycznych gatunków zadrowatych należących do grupy Megaselia brevior (Schmitz) (Diptera: Phoridae). Dwa gatunki: M. angustiata Schmitz i M. parvula Schmitz zostały powtórnie wydzielone jako gatunki ważne. Zaproponowano 3 nowe synonimy. M. aspera Schmitz (na podstawie holotypu samca) został uznany za synonim M. leucozona Schmitz; M. ultrabrevis Schmitz i jego synonim M. pseudobrevior Disney, za synonimy $M$. angustiata. Natomiast $M$. insecta Schmitz został zsynonimizowany z M. oxybelorum Schmitz. Do całej grupy palearktycznych gatunków załączono klucz do ich oznaczania. 